\title{
Identification of factors associated with hand hygiene adherence as a support for creating curriculum for nurses training - a multivariate analysis
}

Anna Garus-Pakowska

Department of Hygiene and Health Promotion, Medical University of Lodz, Poland

(iD) https://orcid.org/0000-0002-1677-8146

Corresponding author: anna.garus-pakowska@umed.lodz.pl

DOI: https://doi.org/10.20883/medical.e444

Keywords: handwashing, glove use, nurses, compliance, barriers, education
Published: 2020-09-30

How to cite: Garus-Pakowska A. Identification of factors associated with hand hygiene adherence as a support for creating curriculum for nurses training - a multivariate analysis. JMS [Internet]. 2020 Sep 30;89(3):e444. doi:10.20883/ medical.e444

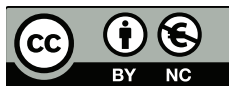

(C) 2020 by the author(s). This is an open access article distributed under the terms and conditions of the Creative Commons Attribution (CC BY-NC) licencse. Published by Poznan University of Medical Sciences

\begin{abstract}
Aim. Handwashing is the easiest way to prevent infection but is often neglected. The purpose of the study was to identify the barriers limiting the respect for hygiene procedures by nurses.

Material and Methods. The study involved direct quasi-participant observation and a questionnaire of 11 nurses in six wards of three hospitals in Poland.

Results. In total, 1,195 observations were conducted in which 3,355 activities requiring hygiene procedures were observed over 8 months. The nurses' knowledge of proper hand hygiene and infection prevention principles were unsatisfactory, with an average value of correct answers in the knowledge test of 8.7 (Max=15). The univariate analysis indicated the following barriers in hand hygiene: emergencies, allergies, or too few dispensers. In multivariate analysis, the application of hygiene procedures depended on the level of education (higher education - worse compliance with the rules) and subjective conviction that handwashing/ glove use was important.

Conclusion. Educational programmes on hand hygiene should focus on the World Health Organisation indications that glove use is not a substitute for handwashing
\end{abstract}

\section{Introduction}

Hand hygiene is a general concept that includes either handwashing with soap and water, antiseptic handwash, antiseptic hand rub, or surgical hand antisepsis. Hand hygiene conserves our health, preventing the spread of respiratory and gastrointestinal infections. Recommendations for proper hand hygiene have been developed by major global institutions dealing with infection prevention and control, e.g., Healthcare Infection
Control Practices Advisory Committee (HICPAC) and World Health Organization (WHO) [1,2].

It is widely recognised that hand hygiene is the cheapest way to prevent the spread of infections, including nosocomial infections. Even during the COVID-19 pandemic, the Centres for Diseases Control and Prevention (CDC) also issued recommendations on handwashing:

- After being in a public place and touching an item or surface that may be frequently touched 
by other people, such as door handles, tables, gas pumps, shopping trolleys, or electronic cashier registers/screens, etc.

, Before touching eyes, a nose, or a mouth to prevent germs from entering our bodies [3].

Therefore, strict compliance with this procedure is extremely important. Unfortunately, it is sometimes forgotten that viruses and bacteria exist and pose a serious threat in the present world. Many authors have reported negligence in the field of hand hygiene in healthcare institutions. The non-compliance relates to the fact that hand hygiene is rare, procedures are performed improperly or the handwashing time is too short [4-6]. The reasons for this have also been described $[2,7-8]$. The current study is distinguished by the following features:

' It is a combination of a survey and observational study while minimising the Hawthorne effect,

, There is a lack of research in Polish literature to help identify thematic areas for the development of interdisciplinary educational programmes in the field of hand hygiene. Such a study may also help to concede educational priorities in other countries.

This study aimed to identify the barriers limiting the compliance of hygiene procedures by nurses.

\section{Materials and Methods}

The study involved the direct observation of nurses in hospital wards over eight months. After the observation, the nurses received questionnaires that assessed their knowledge and attitudes towards hand hygiene and asked them to state the barriers they perceived prevented full compliance of hand hygiene with current recommendations.

\section{Participants}

All nurses from six wards in three hospitals in central Poland.

\section{Measures}

2.2.1. Direct quasi-participant observation of each nurse and registration of all activities was performed in the observation unit ( 1 hour). If at the 60th minute of the observation unit, the nurse was performing any activity that required hand hygiene, the observation continued until the completion of that activity. Three random observation periods were adopted for each employee three times: in the morning, afternoon, and evening. In this case, random selection consisted of observing the first nurse encountered in the ward in a given observation unit. The observation in each ward was preceded by a weekly adaptation of staff to the observer without recording behaviour. The nurses did not know the real purpose of the study to minimise the Hawthorne effect. Elements of hygienic behaviour under observation have been described previously [9-11] and were according to current recommendations [1-2]. The workload was calculated and defined as:

Activity indicator: number of circumstances requiring hand hygiene per unit of time (an hour) [12].

The indicator of effective workload taking into account the time of performing individual medical activities as well as cleaning and administrative work: as a general percentage of time devoted to work per unit of time (an hour) (author's definition).

Observations were recorded on coded sheets.

\section{Questionnaire}

The questionnaire consisted of 15 items regarding hand hygiene issues, with 'true', 'false' or 'don't know' responses. The questions concerned the role of hands in the transmission of infections, transient and constant bacterial microflora, situations in which hand hygiene is required, and the use of protective gloves, the effectiveness of soap and disinfectants, the possibility of not washing hands when protective gloves are used. In addition, two questions were asked: how important it is for the respondent to wash their hands and how important it is for the respondent to wear protective gloves in specific situations. Identification of factors influencing non-compliance with hygiene procedures was made based on the questions regarding barriers limiting the adherence to handwashing and disinfection procedures, and the use of protective gloves.

\section{Data analysis}

The results obtained were subjected to statistical analysis using the statistical package $R$ [13]. The following parameters were calculated for the 
knowledge test: mean value $(\mathrm{Xm})$, standard error of the mean value (sd), minimum value (Min), and maximum value (Max). The logistic regression model was used in the analysis of the co-contribution of many factors determining hygiene behaviour. The multivariate model included the following variables: level of knowledge (test), personal beliefs about the essence of hand hygiene, and the use of protective gloves, education, work experience, and the indicator of effective workload. The level of significance was $p \leq 0.05$.

The coding of observation sheets and surveys allowed the attribution of specific survey responses to the level of compliance with hygiene procedures by a particular nurse. All subjects gave their informed consent for inclusion before they participated in the study. The study was conducted according to the Declaration of Helsinki, and the protocol was approved by the Ethics Committee of Medical University of Łódź (Resolution No. RNN/113/06/KE).

\section{Results}

\section{Characteristics of the study group}

The observed group consisted of 125 nurses working in six wards of the selected hospitals, with 55 nurses in surgical departments, and 70 nurses in non-surgical departments. The questionnaire was completed by 111 nurses ( 6 with higher education, 35 with post-secondary education, 70 with secondary education). Five nurs- es had worked in the profession for less than 5 years, 33 nurses had worked for 6-15 years, 44 nurses had worked for 16-25 years, and 29 nurses had worked for more than 25 years. In total, 111 nurses who were observed and agreed to complete the questionnaire qualified for further multifactorial analysis.

\section{Preliminary analysis}

The average value of correct answers in the knowledge test provided by nurses was $8.7 \pm 2.3$ $($ Min $=0 ;$ Max $=14)$. The level of knowledge of nurses was not affected by the nature of the ward they worked in $(p=0.51)$ or their level of education $(p=0.64)$. Nurses with $16-25$ years of experience were most knowledgeable (Table 1).

Table 1. The level of the nurses' knowledge depending on the variables studied $(\max =15)$

\begin{tabular}{|c|c|c|c|c|}
\hline & Average & $\pm s d$ & Min & Max \\
\hline Type of ward & \multicolumn{4}{|c|}{$(p=0.51)$} \\
\hline surgical & 8.7 & 2.7 & 0 & 14 \\
\hline non-surgical & 8.7 & 1.9 & 4 & 12 \\
\hline Education & \multicolumn{4}{|c|}{$(p=0.64)$} \\
\hline Higher & 8.5 & 1.6 & 6 & 10 \\
\hline Post-secondary & 9.0 & 1.6 & 5 & 13 \\
\hline Secondary & 8.6 & 2.7 & 0 & 14 \\
\hline Seniority (years) & \multicolumn{4}{|c|}{$(p=0.043)$} \\
\hline$\leq 5$ & 7.6 & 1.8 & 6 & 10 \\
\hline $6-15$ & 8.7 & 2.2 & 3 & 14 \\
\hline $16-25$ & 9.3 & 2.4 & 2 & 13 \\
\hline$>25$ & 8.1 & 2.4 & 0 & 12 \\
\hline
\end{tabular}

Note: \pm sd - standard deviation; Min - minimum; Max - maximum; $\mathrm{p}$ - level of significance

Table 2. Multivariate model results for hand hygiene and the use of protective gloves

\begin{tabular}{|c|c|c|c|c|c|c|c|c|c|}
\hline \multirow[t]{2}{*}{ Variable } & \multicolumn{3}{|c|}{$\begin{array}{c}\text { Hand hygiene before patient } \\
\text { contact }\end{array}$} & \multicolumn{3}{|c|}{$\begin{array}{l}\text { Hand hygiene after patient } \\
\text { contact }\end{array}$} & \multicolumn{3}{|c|}{ Use of protective gloves } \\
\hline & OR & $95 \% \mathrm{Cl}$ & p & OR & $95 \% \mathrm{Cl}$ & $\mathrm{p}$ & OR & $95 \% \mathrm{Cl}$ & $\mathbf{p}$ \\
\hline Knowledge & 1.02 & $0.85-1.22$ & 0.81 & 0.95 & $0.85-1.05$ & 0.32 & 1.07 & $0.92-1.23$ & 0.37 \\
\hline Q1 & 1.12 & $0.91-1.38$ & 0.28 & 1.09 & $0.97-1.22$ & 0.14 & 1.17 & $1.01-1.36$ & 0.036 \\
\hline Q2 & 1.46 & $1.11-1.93$ & 0.004 & 1.20 & $1.03-1.39$ & 0.019 & 1.08 & $0.89-1.31$ & 0.44 \\
\hline \multicolumn{10}{|c|}{ Education } \\
\hline Higher & 1.00 & (ref.) & \multirow[t]{3}{*}{0.34} & 1.00 & (ref.) & \multirow[t]{3}{*}{0.023} & 1.00 & (ref.) & \multirow[t]{3}{*}{0.017} \\
\hline Post-secondary & 0.40 & $0.08-1.92$ & & 0.52 & $0.21-1.30$ & & 0.27 & $0.08-0.92$ & \\
\hline Secondary & 0.33 & $0.08-1.37$ & & 0.36 & $0.16-0.80$ & & 0.21 & $0.07-0.63$ & \\
\hline \multicolumn{10}{|c|}{ Seniority } \\
\hline $1-5$ & 1.00 & (ref.) & \multirow[t]{4}{*}{0.24} & 1.00 & (ref.) & \multirow[t]{4}{*}{0.15} & 1.00 & (ref.) & \multirow[t]{4}{*}{0.22} \\
\hline $6-15$ & 4.25 & $0.59-30.47$ & & 2.16 & $0.98-5.35$ & & 2.98 & $1.02-8.75$ & \\
\hline $16-25$ & 5.42 & $0.75-38.96$ & & 2.31 & $0.99-5.39$ & & 2.40 & $0.82-7.01$ & \\
\hline$>25$ & 4.16 & $0.53-32.35$ & & 1.65 & $0.66-4.12$ & & 2.74 & $0.86-8.74$ & \\
\hline Workload indicator & 1.04 & $0.99-1.10$ & 0.12 & 1.00 & $0.96-1.03$ & 0.78 & 1.04 & $1.00-1.08$ & 0.061 \\
\hline
\end{tabular}

Note: OR - Odds Ratio; $95 \% \mathrm{Cl}-95 \%$ Confidence Interval; p-level of significance; $\mathrm{Q} 1$ - question "how important is washing your hands for you?"; 02 - question "how important it is for you to wear protective gloves?" 
According to the nurses, the most common factors that may affect non-compliance with hand hygiene were: emergencies $(75.68 \%)$, skin irritations, allergies (49.55\%), and lack of washbasins and dispensers $(29.73 \%)$. Similarly, the reasons for not wearing protective gloves were: skin irritations and latex-allergies (64.86\%), emergencies $(57.66 \%)$ as well as the deterioration of manual ability (53.15\%).

\section{Multivariate analysis}

During the observational study, 1,195 observations were performed, recording a total of 3,355 activities requiring hygiene procedures. The nurses applied proper hand hygiene in only $15 \%$ of cases, and protective gloves in $48.3 \%$ of the circumstances requiring it. The multivariate model indicated that education significantly influenced the handwashing and not wearing protective gloves, with more highly educated nurses practising hygiene procedures less frequently. In addition, the nurses for whom the use of protective gloves was very important at work washed their hands less often both before and after contact with a patient. Also, the conviction of the importance of handwashing significantly affected the use of protective gloves (Table 2).

\section{Discussion}

The nurses' knowledge regarding the principles of proper hand hygiene and the importance of hand hygiene in the prevention of infections was unsatisfactory, as was the case in other Polish studies [14-16]. The importance of educational programmes in achieving effective hand hygiene has been the subject of many studies around the world.

Pittet et al. conducted a comprehensive threeyear educational programme aimed at increasing effective hand hygiene, thus indicating the reduction of hospital infections and hospital transmission of bacterial microflora, including methicillinresistant Staphylococcus aureus (MRSA), achieved a significant increase in compliance with adopted procedures from $47.6 \%$ in 1994 [12] to $66.2 \%$ in 1997 [17]. During the same period, the overall hospital infection rate decreased from $16.9 \%$ to $9.9 \%$, and the number of reported MRSA strains dropped from 2.16 to $0.93 / 10,000$ person-days [17].
A steady increase in hand hygiene was observed in a hospital in Buenos Aires from 23.1\% to $73.8 \%$ after the implementation of an educational programme in intensive care wards over a two-year period. At the same time, the number of nosocomial infections decreased from 47.55 to $27.93 / 1,000$ person-days [18]. Grayson et al. also reported a decrease in the frequency of MRSA infections with an increase in the frequency of compliance with hand hygiene procedures from $21 \%$ to $47 \%$ over two years in six Australian hospitals [19].

Gordin et al. observed a decrease in nosocomial MRSA and VRE (vancomycin-resistant Enterococcus) infections over a 6-year period, after widespread access to alcohol disinfection of hands [20]. Similarly, Johnson et al. reported an increase in the level of compliance with hygiene procedures (from $21 \%$ to $42 \%$ ) along with a decrease in hospital MRSA infections as the result of an educational programme combined with the improvement of the availability of hand disinfectants, indicating the importance of hand disinfection in preventing cross transmission of microorganisms [21].

Cross transmission is favoured by the survival of microflora on hospital surfaces. Most Gram-positive bacteria, such as Enterococcus spp. (including VRE), S. aureus (including MRSA), or Streptococcus pyogenes, and Gram-negative bacteria such as Acinetobacter spp. or Klebsiella spp. can survive on surfaces for many months. Spore-producing bacteria such as Clostridioides difficile survive the longest on surfaces [22]. Currently, the biggest challenge in fighting infections is the development of resistance by microbes, and recently, the most serious threat has been the spread of Carbapenemase-producing Enterobacterales (CPE). In Poland, the isolated number of strains producing carbapenemase increases every year, including NDM (New Delhi metallo$\beta$-lactamase), VIM (Verona integron-encoded metallo- $\beta$-lactamase), KPC (Klebsiella pneumoniae carbapenemase), and OXA-48 (OXA-48like carbapenemases) [23]. Infections caused by multidrug-resistant (MDR) organisms are associated with increased patient mortality [24].

In health promotion, it is essential to diagnose the problem, then implement appropriate prevention programmes. Hand hygiene is a similar matter. First, the barriers to appropriate hand hygiene 
must be identified to allow the design of targeted educational programmes. To the author's knowledge, such research that would combine multifactor analysis using tools in the form of participant observation and a questionnaire has not been published in Poland.

In this study, the univariate analysis indicated the following barriers in hand hygiene: emergencies, allergies, or too few dispensers, which is in line with other studies [25]. To reduce these barriers, there would be a need to focus on the distribution of individual hygiene dispensers, which every nurse could carry and use when necessary. However, such actions do not always bring the expected results [26]. Perhaps less allergenic agents or better-quality gloves should be purchased, which would be more acceptable to users. Finally, hospital wards should be equipped with more dispensers. Surprisingly, the multivariate analysis revealed that nurses who thought it important to wash their hands wore protective gloves significantly less often. A similar dependence was observed in two subsequent models: the nurses, for whom it was important to use protective gloves, significantly washed/disinfected their hands less often both before and after contact with patients. This finding indicates that the belief that the use of protective gloves can replace hand washing and disinfection. Fuller et al. also observed that the rate of compliance with hand hygiene was significantly lower when gloves were worn [27].

The recommendations indicate that putting on gloves does not negate hand hygiene procedures [1], therefore, the identification of barriers limiting the respect of hygiene procedures may be more effective in multivariate models that take into account the strength of simultaneous interaction of several factors. Hand hygiene training programmes should therefore consider the factors that nurses perceive as barriers (e.g. poor quality disinfectants, poorly placed dispensers) as well as those that result from in-depth analysis.

\section{Conclusions and Perspectives}

Educational programmes on hand hygiene should focus on the indications of the World Health Organization that glove use is not a substitute for handwashing [1].
Acknowledgements

The author thanks Mr Andrzej Olczyk for his help in the data collection.

\section{Limitations of the Study}

The study was designed to avoid the Hawthorne effect, however, it cannot be completely excluded. Also, it should be remembered that the data obtained from surveys are always subjective.

\section{Author Contributions}

Anna Garus-Pakowska conceptualised and designed the study, analysed and interpreted the data, drafted the manuscript.

\section{Conflict of interest statement}

The authors declare no conflict of interest.

\section{Funding sources}

There are no sources of funding to declare.

\section{References}

1. Boyce J, Pittet D. Healthcare Infection Control Practices Advisory Committee and the HICPAC/SHEA/ APIC/IDSA Hand Hygiene Task Force. Guideline for hand hygiene in health-care settings. MMWR Morbid. Mortal. Wkly. Rep.. 2002 Oct 25;51(RR-16):1-45.

2. WHO Guidelines on Hand Hygiene in Health Care. First Global Patient Safety Challenge. Clean Care is Safer Care. WHO Press, Geneva 2009. http://www. who.int/gpsc/5may/tools/who_guidelines-handhygiene_summary.pdf. Accessed 2020 May 27.

3. Handwashing: Clean Hands Save Lives. www.cdc. gov/handwashing/when-how-handwashing.html. Accessed 2020 May 27.

4. Price L, Melone L, Cutajar E, Blane L, Gozdzielewska L, Young M, McAloney-Kocaman K, Reilly J. Investigating the effect of preparation for and participation in a hand-sanitizing relay on nursing students' ability to recall the WHO 6-step hand hygiene technique. American Journal of Infection Control. 2018 Nov;46(11):13041306. https://doi.org/10.1016/j.ajic.2018.04.222

5. Wałaszek M, Kołpa M, Wolak Z, Różańska A, Wójkowska-Mach J. Poor Hand Hygiene Procedure Compliance among Polish Medical Students and Physicians-The Result of an Ineffective Education Basis or the Impact of Organizational Culture?. International Journal of Environmental Research and Public Health. 2017 Sep 7;14(9):1026. https://doi.org/10.3390/ijerph14091026

6. Kingston L, O'Connell N, Dunne C. Hand hygienerelated clinical trials reported since 2010: a systematic review. Journal of Hospital Infection. 2016 Apr;92(4):309-320. https://doi.org/10.1016/j. jhin.2015.11.012

7. Pittet D. Improving Adherence to Hand Hygiene Practice: A Multidisciplinary Approach. Emerging Infectious Diseases. 2001 Apr;7(2):234-240. https://doi. org/10.3201/eid0702.010217

8. Gluyas H. Understanding non-compliance with hand hygiene practices. Nursing Standard. $2015 \mathrm{Apr}$ 29;29(35):40-46. https://doi.org/10.7748/ns.29.35.40. e9929 
9. Garus-Pakowska A, Sobala W, Szatko F. Observance of hand washing procedures performed by the medical personnel before patient contact. Part I. International Journal of Occupational Medicine and Environmental Health. 2013 Jan 1;26(1). https://doi. org/10.2478/s13382-013-0092-4

10. Garus-Pakowska A, Sobala W, Szatko F. Observance of hand washing procedures performed by the medical personnel after the patient contact. Part II. International Journal of Occupational Medicine and Environmental Health. 2013 Jan 1;26(2). https://doi. org/10.2478/s13382-013-0094-2

11. Garus-Pakowska A, Sobala W, Szatko F. The use of protective gloves by medical personnel. International Journal of Occupational Medicine and Environmental Health. 2013 Jan 1;26(3). https://doi.org/10.2478/ s13382-013-0095-1

12. Pittet D. Compliance with Handwashing in a Teaching Hospital. Annals of Internal Medicine. 1999 Jan 19;130(2):126. https://doi.org/10.7326/0003-4819130-2-199901190-00006

13. The R Project for Statistical Computing. https:// www.r-project.org. Accessed 2020 March 15.

14. Wałaszek M, Kołpa M, Wolak Z, Różańska A, Wójkowska-Mach J. Patient as a Partner in Healthcare-Associated Infection Prevention. International Journal of Environmental Research and Public Health. 2018 Mar 29;15(4):624. https://doi.org/10.3390/ijerph15040624

15. Różańska A, Wójkowska-Mach J, Bulanda M. Work experience and seniority in health care vs. medical students' knowledge of selected hand hygiene procedures. Medycyna Pracy. 2016 Oct 4;67(5):623-633. https://doi.org/10.13075/mp.5893.00440

16. Kołpa M, Grochowska A, Gniadek A, Jurkiewicz B. Level of knowledge among medical personnel about infections transferred through direct contact results of questionnaire survey. Przegląd Epidemiologiczny. 2015;69:503-6.

17. Pittet D, Hugonnet S, Harbarth S, Mourouga P, Sauvan V, Touveneau S, Perneger TV. Effectiveness of a hospital-wide programme to improve compliance with hand hygiene. The Lancet. 2000 Oct;356(9238):1307-1312. https://doi.org/10.1016/ s0140-6736(00)02814-2

18. Rosenthal VD, Guzman S, Safdar N. Reduction in nosocomial infection with improved hand hygiene in intensive care units of a tertiary care hospital in Argentina. American Journal of Infection Control. 2005 Sep;33(7):392-397. https://doi.org/10.1016/j. ajic.2004.08.009

19. Grayson ML, Jarvie LJ, Martin R, Johnson PDR, Jodoin ME, McMullan C, Gregory RHC, Bellis K, Cunnington $K$, Wilson FL, Quin D, Kelly A. Significant reductions in methicillin-resistant Staphylococcus aureus bacteraemia and clinical isolates associated with a multisite, hand hygiene culture-change program and subsequent successful statewide roll-out. Medical Journal of Australia. 2008 Jun;188(11):633-640. https:// doi.org/10.5694/j.1326-5377.2008.tb01820.x

20. Gordin FM, Schultz ME, Huber RA, Gill JA. Reduction in Nosocomial Transmission of Drug-Resistant Bacteria After Introduction of an Alcohol-Based Handrub. Infection Control \& Hospital Epidemiology. 2005 Jul;26(7):650-653. https://doi.org/10.1086/502596

21. Johnson PDR, Martin R, Burrell LJ, Grabsch EA, Kirsa SW, O'Keeffe J, Mayall BC, Edmonds D, Barr W, Bolger C, Naidoo H, Grayson ML. Efficacy of an alcohol/chlorhexidine hand hygiene program in a hospital with high rates of nosocomial methicillin-resistant Staphylococcus aureus (MRSA) infection. Medical Journal of Australia. 2005 Nov;183(10):509-514. https://doi.org/10.5694/j.1326-5377.2005.tb07151.x

22. Pawlik K, Mączyńska A, Fleischer M, Hryniewicz W, eds. Kontrola środowiska szpitalnego w zapobieganiu zakażeniom wywoływanym przez wieloantybiotykooporne patogeny alarmowe. Warszawa: Narodowy Instytut Leków; 2020.

23. Literacka E, Żabicka D, Hryniewicz W, Gniadkowski M, eds. Dane Krajowego Ośrodka Referencyjnego ds. Lekowrażliwości Drobnoustrojów (KORLD) dotyczące pałeczek Enterobacterales wytwarzających karbapenemazy NDM, KPC, VIM i OXA-48 na terenie Polski w latach 2006-2018. Warszawa: Narodowy Instytut Leków; 2019.

24. Munita JM, Arias CA. Mechanisms of Antibiotic Resistance. Microbiology Spectrum. 2016 Apr 1;4(2). https:// doi.org/10.1128/microbiolspec.vmbf-0016-2015

25. Diwan V, Gustafsson C, Rosales Klintz S, Joshi SC, Joshi R, Sharma M, Shah H, Pathak A, Tamhankar AJ, Stålsby Lundborg C. Understanding Healthcare Workers Self-Reported Practices, Knowledge and Attitude about Hand Hygiene in a Medical Setting in Rural India. Kumar S. PLOS ONE. 2016 Oct 6;11(10):e0163347. https://doi.org/10.1371/journal. pone. 0163347

26. Keller J, Wolfensberger A, Clack L, Kuster SP, Dunic M, Eis D, Flammer Y, Keller DI, Sax H. Do wearable alcohol-based handrub dispensers increase hand hygiene compliance? - a mixed-methods study. Antimicrobial Resistance \& Infection Control. 2018 Nov 23;7(1). https://doi.org/10.1186/s13756-018-0439-5

27. Fuller C, Savage J, Besser S, Hayward A, Cookson B, Cooper B, Stone S. "The Dirty Hand in the Latex Glove": A Study of Hand Hygiene Compliance When Gloves Are Worn. Infection Control \& Hospital Epidemiology. 2011 Dec;32(12):1194-1199. https://doi. org/10.1086/662619 